\title{
Karkonosze jako idealny górski krajobraz na przełomie XVIII i XIX wieku
}

\author{
https://doi.org/10.19195/2084-4107.13.9
}

Karkonosze przyciągały podróżników już od najdawniejszych czasów. Pomijając kwestię pielgrzymek — na przykład na wierzchołek Śnieżki czy ku źródłom Łaby — należy podkreślić, że początkowo wyprawy w górskie, trudno dostępne tereny podejmowano głównie w celach praktycznych. Podróżnicy przybywali tutaj z zamiarem łowienia zwierzyny, zbierania leczniczych ziół, szukania drogocennych minerałów i metali. Niektórzy poddawali się zabiegom leczniczym z wykorzystaniem świeżego, górskiego powietrza oraz wody z wielu bijących w Karkonoszach źródeł ${ }^{1}$. W ostatnim trzydziestoleciu XVIII wieku pojawiły się nowe źródła inspiracji górskich wypraw. Dominujący wcześniej czynnik użyteczności ustąpił innym motywom, wśród których można wymienić zainteresowania przyrodoznawcze oraz potrzebę przeżyć estetycznych. Ich znaczenie dobrze ilustruje dzieło Josepha Karla Eduarda Hosera Das Riesengebirge in einer statistisch-topographischen und pittoresken Übersicht (1804)2. Już na wstępie autor wyodrębnia trzy główne typy turystów odwiedzających Karkonosze, dzieląc ich na chcących „obserwować”, „bawić, cieszyć się i przeżywać” i w końcu tych, którzy pragną „uzdrowienia" 3 .

Jeśli poszukujemy źródeł powstania wyobrażenia Karkonoszy jako modelu idealnego górskiego krajobrazu i jednocześnie odpowiedzi na pytanie, co stanowi istotę jego idealizacji, to w kontekście klasyfikaji zaproponowanej przez Hosera wydaje się oczywiste, że należy tu wskazać trzy wspomniane w tytule niniejszego artykułu aspekty — piękno, wiedzę i użyteczność. Każda z tych kategorii z pewnością zasługuje na dalsze omówienie, mając odrębną historię, znaczenie i potencjał oraz pewien wyraźny sposób artykulacji. Ze względu jednak na ograniczoną objętość tekstu skupimy się wyłącznie na pierwszej z nich, czyli na pięknie. Jest ono bowiem podstawowym przedmiotem zainteresowania podróżników reprezentujących drugi typu wyodrębniony przez Hosera. Kryterium piękna wypadnie uznać za konstytutywny element ówczesnego wyobrażenia o Karkonoszach jako wariancie idealnego górskiego krajobrazu.

${ }^{1}$ Więcej zob. Karkonosze: przyroda, historia, życie, red. J. Flousek et al., Praha 2007, s. 435442, 447-460, 485-490.

2 Plik zawierał również przewodnik po Angeitung das Riesengebirge auf die zweckmassigste Art zu bereisen, inne treści obejmują wiedzę geograficzną, naukową, etnograficzną i dalsze uwagi.

3 J.K.E. Hoser, Das Riesengebirge in einer statistisch-topographischen und pittoresken Uebersicht mit erläuternden Anmerkungen und einer Anleitung dieses Gebirge auf die zweckmässigste Art zu bereisen: Mit schwarzen und ausgemahlten Kupfern und einem Musikblatte. Zweyter und letzter Band, Wien 1804, s. 5. 


\section{Widzieć piękny górski krajobraz}

Podróżnik, którego celem jest „poznanie i pocieszenie” („Genuss und Unterhaltung"), według Hosera znajduje upodobanie w terenach górskich podobnie jak w ,przedmiotach oddziałujących na jego poczucie estetyczne"4. W tym wypadku tymi przedmiotami są wyłącznie najróżniejsze naturalne scenerie („Naturscene”/ „Naturszene “ $)^{5}$, które podróżnik znajduje ,gdziekolwiek obróci wzrok”6. Ważne jest tu słowo „scena/sceneria”, ponieważ pokazuje, że przyroda nie ma być odbierana fragmentarycznie, przeciwnie — każdy jej komponent i każde zjawisko mają się złożyć na widowisko, obraz lub to, co Hoser często nazywa teatralnym przedstawieniem (Schauspiel) ${ }^{7}$. Spotkanie z przyrodą zmienia się zatem w patrzenie na krajobraz.

Koncepcja krajobrazu pojmowanego jako „fenomen definiowany przez oko” dopełnia dalsze możliwe warianty rozumienia tego pojęcia (przykładowo kraina jako pewien geograficzny obszar, kraina jako rezultat malowniczości/pejzaż, kraina jako efekt wyobraźni itp. ${ }^{8}$ ). Początków takiego sposobu interpretowania przestrzeni, który historyk Peter De Bolla określił jako „the education of the eye", można upatrywać w XVIII wieku, a jego rozwinięcia przede wszystkim we współczesnej socjokulturowej praktyce, spopularyzowanej poprzez różne podręcznikowe dyskursy teoretyczne ${ }^{9}$. Praktyka ta objawiała się w wielu dziedzinach, dotyczyła malarstwa, architektury, sztuki projektowania ogrodów i przyrodoznawczych szkiców czy eksperymentów, wszędzie tam oko mogło być wyćwiczone do tego, na co i w jaki sposób ma patrzeć. Natura i krajobraz „w tej opowieści zagrały jedną z kluczowych ról" 10 .

Z perspektywy tej praktyki pamiętnik z podróży Hosera jawi się nie tylko jako przewodnik po mało znanym regionie i opis autentycznego doświadczenia konkretnego miejsca. Dla ówczesnego czytelnika mógł być też instrukcją, która pokazywała, co może w górach zobaczyć „wyszkolone oko”, i sugerującą, jak można patrzeć na góry i je wartościować (przypomnijmy, że wciąż chodziło o teren, który nie budził powszechnego zainteresowania, lecz raczej obawy). Ten sposób rozumienia dzieła Hosera w wymiarze emblematycznym potwierdza powtarzają-

${ }^{4}$ Dokładniej ,wohin der Blick sich wendet, findet er die Gegenstände, die Bald mit Sanfter Rührung, Bald mit Gewaltsamer Erschütterung auf sein ästhetisches Gefühl wirken” —ibidem, s. 25.

5 Ibidem, s. 24.

${ }^{6}$ Ibidem, s. 25.

7 Przykładowo, patrząc na Úpski wodospad (ibidem, s. 81) lub scenę zachodu słońca obserwowaną nad szczytami górskimi (ibidem, s. 192).

${ }^{8}$ S. Swaffield, Landscape as the way of knowing the world, [w:] The Cultured Landscape: Designing the Environment in the 21st Century, red. S. Harvey, K. Fieldhouse, J. Hopkins, Abingdon-New York 2005, s. 8.

9 P. De Bolla, The Education of the Eye: Painting, Landscape, and Architecture in Eighteenth Century Britain, Stanford, CA 2003. Na język czeski można by przetłumaczyć jako „praktyka szkolonego oka" (,praxe školeného oka”).

10 Ibidem, s. 12. 
ca się figura stylistyczna - synekdocha, w myśl której oko zastępuje całe ciało oraz myśl podróżnika i za jego pośrednictwem rysuje obraz krainy ${ }^{11}$. Wzrokowy związek z przestrzenią wyróżnia się dzięki kolejnym czasownikom połączonym z widzeniem: podróżnik Hosera ma przede wszystkim patrzeć, przyglądać się, obserwować, badać i ogólnie zajmować się dalszymi aktywnościami związanymi z postrzeganiem. Mimo to Hoser uważa te czynności niemal za powinność podróżnik karkonoski miał wyszukiwać miejsca widokowe ${ }^{12}$ i z różnych stron zdobywać szczyt Śnieżki, by móc podziwiać góry w odmiennych warunkach pogodowych i o różnej porze dnia, gdyż: „Nie da się opisać, jaki czar się rozlega w mieniącym się oświetleniu tych już wystarczająco malowniczych scen, widziałem te nieporównywalne z niczym obrazy o różnych porach dnia i z różnych miejsc po czeskiej i śląskiej stronie (gór) i z zachwytem je podziwiałem" "13. Zmienność, niestałość czy dynamiczność nie musi być spowodowana wyłącznie zmianą warunków, lecz także rozwarstwieniem przestrzeni, dzięki której Karkonosze są widziane jako przestrzeń jaskrawych kontrastów: naprzeciw arkadyjskich łąk znajdują się groźne skalne pustkowia, spokojnie bulgoczący potoczek, wijący się na wskroś ukwieconej łąki, zmienia się w naprędce spadający wodospad, a pod ubogim mchem znajdzie podróżnik pięknie kwitnące byliny. Wszelkie zalecenia Hosera, jak patrzeć, prowadzą do wyeksponowania estetycznej wartości miejsc, których opisy odgrywają rolę swoistej instrukcji sposobu widzenia „dzieła natury”:

zmiana oświetlenia, które w górach odgrywa nieskończenie ważniejszą rolę niż na równinach, często zmienia koloryt przestrzeni w taki sposób, że obiekty namalowane rano i po południu z tego samego miejsca, można — jak wie każdy malarz pejzażysta — widzieć zaledwie tylko raz. Szczęśliwe zacienienie właściwych fragmentów, w chwili kiedy możemy uchwycić krajobraz w najlepszej fazie oświetlenia, wywoła silne wrażenie na każdym miłośniku przyrody, nawet jeśli nie jest on poetą bądź malarzem ${ }^{14}$.

11 Przykładowo „das Auge erreicht die breiten und flachen Gebirgsrücken” (J.K.E. Hoser, op. cit., s. 46) lub bardziej rozbudowany akapit: „So wird das erstaunte Auge auf dem Riesengipfel der Koppe bei jeder veränderten Richtung durch einen unendlichen Wechsel der Contraste unaufhörlich gereitzt und entzückt, unterhalten und befriedigt; wohin es blickt, stellen sih ihm neue Wunder dar" ibidem, s. 52-53.

12 „Ich könnte rücksichtlich der ersten Seite wieder unzählige nähere und entferntere Standpuncte anführen, von denen eine Ansicht des Riesengebirges im hohen Grade malerisch, erhaben, reich und genussvoll ausfällt" - ibidem, s. 36.

13 „Es ist unbeschreiblich, welchen Zauber die wechselnde Beleuchtung über diese ohnehin so malerische Scene verbreitet; ich habe dieses unvergleichliche Schauspiel zu verschiedenen Zeiten und an verscheidenen Orten auf böhmischer und schlesischer Seite gesehen, und mit Entzücken bewundert" - ibidem, s. 38 .

14 „Der Wechsel der Beleuchtung, die in Gebirgen eine unendlich wichtigere Rolle spielt, als in der Fläche, verändert oft den Charakter einer Gegend dargestalt, da $\beta$ sie, wie jeder Landschaftsmahler wei $\beta$, aus demselben Standpunkte Früh- und Nachmittags gezeichnet, sich kaum ähnlich sieht. Dieses glückliche Auffinden des wahren Moments, eine Gegend in ihrer vortheilhaftesten 
Prezentowana przez Hosera koncepcja sposobu wizenia krajobrazu wskazuje, że Karkonosze jawiły się mu jako ideał malowniczego piękna (picturesque beauty, die malerische Schönheit) ${ }^{15}$. Świadczy o tym już sam tytuł dzieła, podobnie jak eksplicytne odwołanie się w przedmowie do koncepcji estetycznych Williama Gilpina ${ }^{16}$. W jego rozważaniach można znaleźć uwagi dowodzące, jak ważnym narzędziem konstruowania krajobrazu były wrażenia wzrokowe. Przykładowo w eseju $O$ malowniczym podróżowaniu (Essay on picturesque travel, 1792) oko w zasadzie zawsze jest określane jako ,pitoresque eye”, czyli instrument, który przyporządkowuje pojedyncze obiekty przyrodnicze do pewnej kompozycji i decyduje o zachodzących pomiędzy nimi relacjach oraz umożliwia odbieranie i ocenianie rozmaitych konstytutywnych elementów krajobrazu, do którego należą drzewa, skały, przepaście, lasy, rzeki, łąki, doliny i góry, a także warunki atmosferyczne i różne efekty towarzyszące naturalnym procesom pogodowym, oddalone obiekty itp. ${ }^{17}$

Hoser nie jest jednak bezwzględnie zależny od Gilpina. Wyobrażenie o pięknie krajobrazu rozszerzył o refleksje odnoszące się do terenów wysokogórskich, do których angielski badacz nie miał zbyt pozytywnego stosunku, ponieważ w jego przekonaniu zakłócały one kontemplację preferowanej przez niego idealnej malowniczości ${ }^{18}$. Wskazuje więc Hoser na przykład na obrazy Alp i sposób kreowania alpejskich krajobrazów w poezji Albrechta Hallera lub w filozoficznych dziełach Jeana-Jacques'a Rousseau ${ }^{19}$, a także podobne sposoby ujęcia specyfiki górskiego krajobrazu podobnych obszarów (Hoser wspomina o szkockim regio-

Beleuchtung zu sehen, wird eine reiche Quelle des Vergnügens für jeden Freund schöner Natur, wenn er selbst auch weder Dichter noch Mahler ist" — ibidem, s. 189.

15 Malowniczość jest zarezerwowana dla krajobrazów, które odznaczają się harmoniczną kompozycją artystyczną spektaklu, ich wyraźną częścią są niskie pagórki na horyzoncie, łagodne cieki wodne i drzewa czy krzewy w pewnych ujmujących kompozycjach (sosny, olchy, wierzby, jarzębiny), a także kolejne elementy i zjawiska (więcej powyżej w tekście). O historii tego pojęcia zob. K. Stibral, O malebnu: estetika př́rody mezi zahradou a divočinou, Praha 2011.

16 J.K.E. Hoser, op. cit., s. 5. Hoser wzmiankuje Gilpina jako autora, który mógłby w ramach swojego obszernego dzieła jeszcze w dosyć prosty sposób wskazać piękno Karkonoszy i żałuje, że tak się jednak nie stało - ibidem.

${ }_{17}$ W. Gilpin, Three Essays: On Picturesque Beauty; on Picturesque Travel; and on Sketching Landscape: To Which is Added a Poem, on Landscape Painting, London 1792, s. 42.

18 Więcej na ten temat zob. cytat $\mathrm{z}$ wskazanego eseju: „The spiry pinnacles of the mountains and castle-like arrangment of the rock give no peculiar pleasure to the pitoresque eye. / Spiczaste szczyty gór i zamek urządzony tak, by przypominał skałę, nie przynoszą żadnej specjalnej przyjemności malowniczemu oku" - ibidem, s. 46. Gilpin postuluje w przypadku kategorii malowniczości w odniesieniu do krajobrazu wprowadzenie „,zwyczajniejszych form”. Irlandzkie Giants Causeway, o których wspomina, są dla niego przykładem nieodpowiednich terenów górskich, które go odpychają.

19 Hoser wspomina Hallera tylko marginalnie (J.K.E. Hoser, op. cit., s. 25), za to postać Rousseau przybliża jako przykład pieszego wędrowca, który w ten sposób dynamicznie wkracza $\mathrm{w}$ estetyczną relację z obserwowanymi przyrodniczymi sceneriami i dla którego natura staje się rzeczywistym sanktuarium, miejscem spokoju i odpoczynku, a także potrzebnej samotności. Por. ibidem, s. 208-209. Hoser cytuje z Wyznania (Les Confessions/Die Bekenntnisse, spisano 1765-1770, pierwszy tom I-IV, wydano 1782; drugi tom VII-XII, wydano 1789). 
nie Highlands, Harzu lub Rudawach $)^{20}$. Potwierdzają one, że nawet przedmioty, których ogrom, ostre kontrasty lub nieład dosłownie atakują umysł odbiorcy, mogą wywoływać mocne przeżycia estetyczne polegające nie tylko na doznaniu przyjemności, ale także wiążące się ze strachem, a nawet z przerażeniem.

Konkretne przykłady godnych podziwu i groźnych scenerii, współtworzących „piękno” Karkonoszy, przywołuje Hoser wielokrotnie. Według Hosera są one dowodem potwierdzającym tezę, że pejzaże Karkonoszy zasługują na miano modelowego idealnego górskiego krajobrazu ${ }^{21}$.

Omawiane przez Hosera piękno Karkonoszy zostało zdefiniowane nie tylko w kategoriach malowniczości, innym bowiem jego istotnym źródłem jest — eksponowana przez estetykę jego czasów - kategoria wzniosłości ${ }^{22}$. Została ona wprowadzona w Anglii przez Edmunda Burke'a i spopularyzowana później na kontynencie, zwłaszcza w środowisku niemieckim, i to nie tylko dzięki recepcji filozoficznych i estetycznych koncepcji Immanuela Kanta ${ }^{23}$. Estetyka wzniosłości zwróciła przede wszystkim uwagę na takie wartościujące spojrzenie na obiekty, które zamiast proporcji, symetrii i zgodności cechowały przeciwstawne właściwości — niejasność, chaotyczność, dynamiczność, zmienność kontrastów, wyłamywanie się z przyjętych konwencji. W tym kontekście doceniono ponownie takie fenomeny martwej i żywej natury, które odznaczały się wskazanymi formami ekspresji (za majestatyczne uznano na przykład: zachód słońca, burzę, rozległe morskie akweny i opustoszałe wysokie góry). I chociaż kategoria wzniosłości wiązała się z aprobatą dla krajobrazów i fenomentów natury innych niż przestrzenie i obiekty widziane przez pryzmat idei malowniczości, to za rozstrzygające uznano społeczne znaczenie wrażenia wizualnego. Nie przypadkiem Burke poświęcił jeden z rozdziałów swojego dzieła O wzniostości (A Philosophical Enquiry into the Origin of Our Ideas of the Sublime and Beautiful, 1757) oku jako głównemu zmysłowemu organowi człowieka, inny zaś nosi wymowny tytuł Why visual objects of great dimension are sublime ${ }^{24}$.

Umiejętność właściwego patrzenia, bez względu na dialektykę malowniczości i wzniosłości krajobrazu, jest kluczowym motywem dzieła Hosera. I chociaż łączy

${ }^{20}$ Na popularność szkockich Highlands wpłynęły szczególnie Pieśni Osjana (1765). Harz został opisany w literaturze przede wszystkim przez J.W. Goethego. Jest to lektura, z którą Hoser, jako intelektualista, był z pewnością zaznajomiony.

${ }^{21}$ Hoser we wstępie decyduje się na porównanie Karkonoszy z Alpami; w porównaniu z Alpami Karkonoszom brakuje „skalnych kolosów pokrytych śniegiem, magicznie zabarwionych wschodzącym i zachodzącym słońcem”, „lodowców na groźnych pustkowiach”, a ,jeziora w arkadycznych dolinach, w których to szmaragdowych taflach jak w lustrze odbijają się zalesione pięty gór" (J.K.E. Hoser, op. cit., s. 3).

${ }^{22}$ Pojęcie było przedmiotem rozważań jeszcze w antyku u Pseudo-Longinosa (1. st. n. 1. Peri hupsuous), ale do dyskursu wejdzie dopiero w XVII wieku, kiedy Longinos został przethumaczony z języka francuskiego na angielski i następnie zostanie spopularyzowane w wieku XVIII. Od tego czasu, prawdopodobnie z wyjątkiem postmoderny (Lyotard), jego znaczenie słabnie. O koncepcji tego pojęcia zob. K. Stibral, Proč je príroda krásná..., s. 62-74.

23 Por. T. Hlobil, K pronikáni Burkova pojednáni o kráse a vznešenu do Prahy (př́nos Augusta Gottlieba Meißnera), „Aluze” 8, 2004, nr 2/3, s. 194-203.

24 E. Burke, op. cit., s. 220-222. 
on w swym obrazie Karkonoszy dwie przeciwstawne tradycje, choć stosuje zarówno koncept malowniczości, jak i wzniosłości, kontrast ten nie jest dla niego przeszkodą, lecz potwierdzeniem idealności Karkonoszy, w których możliwe jest znalezienie właściwie wszystkiego, czego może oczekiwać „zachwycony znawca i miłośnik natury".

\section{Dalsze literackie analogie i modyfikacje}

W momencie ukazania się drukiem utworu Hosera ówczesnym czytelnikom dostępna była już względnie gęsta sieć tekstów i dzieł literackich, których tematem stał się krajobraz Karkonoszy. Obszar Karkonoszy, oprócz beletrystyki²5, przybliżały głównie naukowe dzieła przyrodoznawcze i podróżnicze ${ }^{26}$. Sposób prezentowania w nich karkonoskiego pasma był przy tym bardzo podobny do konwencji stosowanej przez Hosera. Już pierwszy nowożytny opis Karkonoszy - Reisen nach dem Riesengebirge (1777) Johanna Tobiasa Volkmara — zawiera1 opis szlaków, które odznaczały się interesującymi walorami estetycznymi wynikającymi z ich przebiegu. Nie brakowało wśród nich pięknych dolin, charakteryzujących się uporządkowanymi i ładnie zagospodarowanymi wioskami ${ }^{27}$, ani „groźnych skalnych ścian, ostrych szczytów, skalnych dachów, wież, burzliwych, rwących i huczących wodospadów" 28 , a więc elementów malowniczych i groźnych, wzajemnie tworzących jaskrawe kontrasty. Podobny sposób obrazowania krajobrazów karkonoskich można odnaleźć w dziele Beobachtungen auf Reisen nach dem Riesengebirge ${ }^{29}$ (1791). Jego autorem był botanik Tadeusz Hänke. Potwierdza on przede wszystkim znaczenie wizualnego wrażenia przestrzeni:

Dotarliśmy teraz do stromego wywyższenia pod wsią Kalná a przed naszymi oczami otworzył się naraz niemal bezgraniczny, wysoko i daleko ciągnący się łańcuch Karkonoszy. Jest to rzeczywiście słynny, majestatyczny widok!, który duszę wprowadza w podziw, ba za-

${ }^{25}$ W relacjach z podróży szczególnie często wspomina się tomik poetycki Ludwiga Balthasara Trallesa Versuch eines Gedichtes über das Schlesische Riesen-Gebürge (1750).

${ }^{26}$ Spis ówczesnej literatury o Karkonoszach zob. J.K.E. Hoser, op. cit., s. 244-248.

27 J.T. Volkmar, Reisen nach dem Riesengebirge, Bunzlau 1777, s. 9.

28 „Gräsliche Felswände, Spitzen, Bedachungen, Thürme, brausende, stürmende, brüllende Wasserfälle" - ibidem, s. 54.

${ }^{29}$ Chodziło o rezultat ekspedycji przyrodoznawczej w Karkonosze, organizowanej przez Królewskie Czeskie Towarzystwo Naukowe (prekursor Akademii Nauk), które w 1786 roku zdecydowała się organizować wyprawy w Karkonosze. Rzeczywiście w kolejnych latach 1787 i 1788, swoją drogą paralelnie z wyprawami Benedicta de Saussura na Mt. Blanc, te ekspedycje zostały zrealizowane. Każdy ze wspomnianych badaczy miał powierzony obszar przyrodniczy, który miał szczegółowo zbadać i opisać (Jirasek zajmował się mineralogią, Haenke botaniką, Gruber był odpowiedzialny za fizyczny opis Karkonoszy w szerokim tego słowa znaczeniu - obejmujący zjawiska geologiczne, meteorologiczne i klimatyczne lokalizacji, zadaniem Gerstnera było przeprowadzenie dokładnych pomiarów wysokości szczytów). 
chwyt, kiedy człowiek dostrzeże te spiętrzone i ogromne masy ziemi w całej okazałości. Najpierw tu widzi, z jakąś śmiałością łyse, często pokryte warstwami wiecznego śniegu górskie grzbiety, które przez siebie przenikają, i gdzie całą scenerię w tle zamyka Śnieżka, która wysoko nad wszystkimi pozostałymi wznosi swoją skalistą głowę dumnie do nieba. Mój wzrok spoczywał utkwiony i nieporuszony w tych wyżynach: bliższy widok wzruszył moją wyobraźnię w najżywszy sposób i pewien rodzaj strachu i grozy urósł w mojej duszy, kiedy pomyślałem o tym, że już bym łatwo tym szlakiem dotarł do tej najbardziej imponującej części gór ${ }^{30}$.

W anonimowym dzienniku z podróży z końca XVIII wieku Reise in das Riesengebirge und in die umliegenden Gegenden Böhmens und Schlesiens (1799) ${ }^{31}$ określenia dotyczące ówczesnych estetycznych kontekstów zajmują obszerną część tekstu. Mówi się tutaj o „,malowniczej dolinie Úpy”, ,groźnie wysokim wejściu do skalnej groty”, „majestatycznym widoku” itd. Podane przymiotniki nie są w żaden sposób dokładniej wyjaśnione, są ,etykietami”, które wszyscy mogą „zrozumieć”32.

30 „Nun hatten wir die ziemlich steile Anhöhe bei Kallny erreicht, und je[t]zt eröf[f]nete sich auf einmal unsern Augen eine ganz neue überraschende Scene [Szene]. In der Nähe lag sie hiervon unsern Augen, beinahe unübersehbar, die ganze große und weitausgedehnte Kette der Riesengebirge. Wahrlich ein feierlicher, ein majestätischer Anblick! der die Seele in Bewunderung, in Erstauen hinreitzt, wenn man diese Pfeiler des Himmels; diese erhabenen und ungeheuern Erdmassen in ihrem ganzen Umfange; sieht, mit welcher Kühnheit ihre kahlen, oft mit ewigen Schneelasten gedrückten Rücken gruppenweis über einander hervorragen, in deren Hintergrunde die Schneekoppe die Scene schlie $\beta$ t, und hoch über alle die übrigen ihr felsigtes Haupt in die Wolken empor hebt. [...] meine Augen ruheten starr und unverrückt auf diesen Höhen: meine ganze Einbildungskraft war in ihrem nähern Anblicke auf das lebhafteste beschäftigt, und eine Art von Furcht und Schauer bemächtigte sich meiner Seele, wenn ich daran dachte, dass ich auf dieser Reise selbst den ansehnlichtsten Theil dieser Gebirge durchwandern würde" — J. Jirasek, T. Gruber et al., Beobachtungen auf Reisen nach dem Riesengebirg. Mit Kupfern und einer petrographischen Charte, Dresden 1791, s. 53-54; vyznač. - V.F.).

${ }^{31}$ Na podstawie informacji, którymi dysponujemy, możemy wskazać tylko kilka bezspornych cech autora, bardziej szczegółowy rys jego osobowości i okoliczności powstania dzieła pozostają w sferze przypuszczeń. Oczywiste jest, że autor mieszkał w Pradze, skąd pod koniec sierpnia 1796 rozpoczął wędrówkę. Trwała ona nieprzerwanie dwadzieścia osiem dni w napiętej sytuacji politycznej (wojsko napoleońskie przybliżyło się do czeskich granic). Podczas podróży towarzyszyło mu kilku wędrowców, między innymi także Joseph Karl Eduard Hoser, twórca nieco później wydanego rozległego opisu Karkonoszy. Autor ewidentnie należał do elity mieszczańskiej, o czym świadczą jego literackie i artystyczne spojrzenie oraz wiedza na temat przyrodoznawstwa, której znajomość była niemal powinnością każdego członka uprzywilejowanych warstw społecznych.

32 Dodajmy, że w tym miejscu pojawia się na nowo określenie „romantyczny/a”, które zasługuje na bardziej rozległy wykład. Możemy się powołać chociażby na twierdzenie De Bolla, który wskazuje na bliskość koncepcji wzniosłości i romantyzmu; według jego opinii dyskurs o wzniosłości (discourse on the sublime) jest fenomenem XVIII wieku, podczas gdy dyskurs o wzniosłości (discourse of the sublime) należy do określeń romantyzmu i XIX wieku (streszczenie książki De Bolla: The Discourse of the Sublime, więcej zob. R. Hoffmann, I. Whyte, Beyond the Finite: The Sublime in Art and Science, New York 2011, s. 81). 
Przyglądając się czeskiemu piśmiennictwu z początku XIX wieku w kontekście podobnych tematów i gatunków (podróżniczych) zawierających charaterystykę karkonoskich szlaków, można zauważyć wysoki stopień utrwalenia omawianych koncepcji ${ }^{33}$. Można je nawet sklasyfikować jako stereotypy, które czescy pisarze z zamiłowaniem przejmują i kontaminują, czasem także rozszerzają znaczeniowo. W centrum uwagi czeskich podróżników, na przykład Josefa Myslimíra Ludvíka, znajdują się komponenty natury i kategorie zjawisk współtworzące specyficzny koloryt danego fragmentu przestrzeni, obserwowane przez pryzmat wzajemnych interakcji. Integrującym elementem jest tutaj wizualne wrażenie, krajobraz jest odkrywany dzięki widokom, najlepiej percypowanym z wysokości; jest to „oko”, które błądzi w przestrzeni i umożliwia ich odbiór i wartościowanie ${ }^{34}$. Podróżnik budzi się przed „teatrem” natury.

Czeski autor doskonale wie, jak zadowolić czytelnika i jaki obraz górskiej krainy przypadnie do gustu jego publiczności. Wybiera więc miejsca „wzniosłe” i „,przyjemne”, pokazuje obiorcy „pustkowia opustoszałe i martwe” i „doliny powabne”, ze szczytu Śnieżki zaleca obserwację „straszliwej wrzawy mgławej, zimnej jutrzenki”, „wzniosłego słońca wschodu” i ,spokojnego zachodu”, a także gwarantuje „przyjemność jasnej gwieździstej nocy”35. Kontrast „malowniczości” i „wzniosłości” staje się główną regułą konstrukcyjną tekstu:

[Widzieliśmy] straszliwe skalne stromizny, martwą ciszę... przyroda już tutaj jakby obumarła, żadnego zielonego drzewka, żadnego kolorowego kwiatka, żadnego szemrzącego potoczka..., [ale po chwili] już podziwialiśmy delikatny błękit nieba, bezdźwięczne powietrze, wspaniałość żarliwego słońca... [rozgościło] się w nas błogie uczucie wiecznego spokoju $^{36}$.

33 Były to (w porządku chronologicznym): Josef Myslimír Ludvík Myslimír, po horách krkonošských putující (1824), František Nečásek Cesta na Sněžku (1832), Jan Nepomuk Lhota Cesta na Pecku (1834), Karel Antoniewicz, przekład J.V. Podlipský Zpomínky na cestu přes Krkonoše (1838), František Tomsa Př́telské dopisy z cesty na Sněžku (1845), Karel Hanuš Cesta na Sněžku, Josef Václav Frič Cesta přes Friedland na Krkonoše (1846), Václav Hanuš Reischel Cesta na Sněž$k u$ (1847). Nie można zapomnieć o utworach niemieckojęzycznych czeskich autorów (Jan Erazim Vocel Skizzen aus Riesengebirge (1841) lub chętnie czytanym w czeskim środowisku Wanderungen durch das Riesengebirge (1840) Karla Herloše-Herlosßohna).

34 „Wspanialszy jest owszem teatr na tym wzniosłym miejscu, niźli na równinach. Horyzont jest nieskończenie przestronniejszy; słońce wcześniej wschodzi, a jutrzenka w czystym jasnym powietrzu jest wspanialsza, wzrok daleko, wysoko i głęboko przenika przestrzeń. Piękny widok na światło, wciąż głębia wpływająca do dolin; rozproszenie ciemnych cieni, na nizinach rozpostartych; przemiany barw i światła; cienie gór, skał i przepaści, które się bielą w rozpostartym świetle: to wszystko niebiańską pociechą napełnia duszę" - J.M. Ludvík, Myslimír po horách krkonošských putující, Liberec 2016, s. 17; lub „Właśnie wodzi oko po najważniejszym grzbiecie w prawo na zachód, spocznie na szczycie Małego Szyszaka i Śmielca, przycupnie pod górą w dole na wiosce Podgórzyn (Giersdorf), znów się wzniesie i zawiśnie na średniowiecznym zamku Chojnik, rozpozna Wielki Szyszak i pod nim w prawo Śnieżne Kotły w ostrym świetle” — ibidem, s. 34.

35 J.M. Ludvík, op. cit., s. 19.

36 Ibidem, s. 2. 
Znamienne jest, że już w 1824 roku poszczególne koncepcje krajobrazu, takie jak malowniczy i wzniosły, ale także idylliczny i romantyczny, nie były od siebie bardzo odległe, ale wzajemnie się krzyżowały i nawarstwiały. Jest to jedna $\mathrm{z}$ tendencji literatury czeskiej, która w piśmiennictwie dotyczącym Karkonoszy utrzymała się jeszcze przez długi czas. Szczególnym przypadkiem jest tutaj zapewne twórczość najpopularniejszego czeskiego romantyka Karla Hynka Máchy, którego Pout’ krkonošská (1833, tylko rękopis) przedstawia skrajnie subiektywny obrazy przyrody i krajobrazu, który wyznacza przestrzeń metafizycznych doznań i odczuć przypominających o przemijalności człowieka w opozycji do wieczności natury. Jednakże obrazy Máchy wywodzą się z wcześniejszej tradycji i w oderwaniu od niej stają się nieczytelne. To, że w dziele Máchy opis gór nacechowany jest wzajemnym przenikaniem się kontrastujących z sobą koncepcji estetycznych malowniczości i wzniosłości, nie ma żadnego związku z faktem, że Mácha przed swoją rzeczywistą podróżą w Karkonosze przestudiował przewodnik po Karkonoszach J.K.E. Hosera i do swojego szkicownika wypisał fragmenty dotyczące najpiękniejszych widoków ${ }^{37}$. W jego wizji jest to powabnie falujący krajobraz, z dominantą „rozkosznie kwiecistych łąk”, skąd „kiełkujące zboże przyjemnie i słodko zapachniało”, wznoszą się „,ciemne” góry, w których „ptaki i zwierzęta omijają tę krainę, ani drzewo, ani kwiat tutaj nie wzejdzie, tylko człowiek jedynie ciśnie się zawsze wyżej i wyżej w nieba błękit, a nie odnajduje nic, tylko szumiący tajemniczo mech i zimny śnieg"38.

Również wcześniejszy tekst Josefa Václava Friča (następcy Máchy) Cesta přes Friedland na Krkonoše (1846; Podróż przez Friedland w Karkonosze) operuje podobnymi kontrastami. Pisarz w krótkich odstępach tekstu zestawia obok siebie widoki spokojnych osad ludzkich usytuowanych nad potokiem i groźnych przepaści Śnieżnych Kotłów, zachwycający zmierzch, gdy „księżyc całuje srebrne góry" z zatrważającą mgłą i deszczem, burzliwy wodospad Szklarki, miotający się w „przepaści bez dna”, i ,szeroką łąkę ze źródłami sławnej Łaby”39. Frič, co godne podkreślenia, nie wchodzi w Karkonosze pozbawiony oczekiwań dotyczących charakteru i estetyki obrazów, które tutaj odnajdzie. Przeciwnie — jego wyobrażenia nawiązują do rozległej tradycji estetycznych koncepcji powstałych

37 K.H. Mácha, Dílo Karla Hynka Máchy, sv. 3. Deniky - zápisníky - dopisy, red. K. Janský, Praha 1950, s. 189-191). Mácha odbył wędrówkę w Karkonosze w lecie 1833 roku, skrupulatnie przygotował drogę, szczegółowy plan podróży jest ujęty w jego dziennikach. Jego kompanem był przyjaciel Eduard Hindl. Głównym celem wyprawy była Śnieżka. W księdze szczytowej Śnieżki widnieje zachowany wpis z dnia 28 sierpnia 1933 roku w formie czterowersowego utworu: Sněžka zdvíhá čelo jasné,/ Krkonošů lampa plane,/ Krvavé až zoře zhasne — / Zlaté Čechům slunce vstane („Śnieżka wznosi czoło jasne/ Karkonoszy lampa płonie/ Zanim zgasną krawe zorze — / Złote Czechom słońce wstanie. Zob. J. Kolbuszewski, Czeskie wiersze w księgach pamiatkowych Śnieżki, „Sborník prací Filozofické fakulty Brněnské univerzity. Studia Minora Facultatis Philosophicae Universitatis Brunensis D” 32 1985, s. 136-137). Utwór jest częścią znanego wiersza Baláda (Ballada) wydrukowanego w roku 1842 w słowackim almanachu J.M. Hurbana Nitra.

38 K.H. Mácha, Prózy, red. Z. Hrbata, M. Procházka, M. Charypar, Praha 2008, s. 15, 22.

39 J.V. Frič, Cesta přes Friedland na Krkonoše, „Poutník” 1, 1846, s. 141-143. 
w drugiej połowie XVIII wieku i rozbieżności pomiędzy tym co zaobserwowane a wyobrażone stają się dla podróżnika źródłem frustracji. W ten sposób Frič żali się, że przez mgłę i deszcz przy przejściu Wielkiego Szyszaka stracił możliwość „zobaczenia tego, co mieli zobaczyć”:

Co najpiękniejszego tutaj, tę rozległą piękną krainę, całkowicie utraciliśmy, bowiem zachmurzone niebo całkiem ją zasłoniło. Szliśmy więc około Sedmidoli, przepaści, które podobno miały być romantyczne my na nieszczęście nie zobaczyliśmy nic ${ }^{40}$.

Oko Friča jest już całkiem dobrze „wyćwiczone”, nie jest zatem możliwe, by nie wiedział, na co zwrócić uwagę, podróżując przez Karkonosze.

Z języka czeskiego przełożyła Anna Brzezińska-Winkiel

${ }^{40}$ Ibidem, s. 141. 